\title{
Education in Times of COVID-19: Looking for Silver Linings in Southern Africa's Educational Responses
}

\author{
Mutizwa Mukute, Buhle Francis, Jane Burt and Ben de Souza, Rhodes University,
}

South Africa

\begin{abstract}
Coronavirus Disease 2019 (COVID-19) has disrupted socio-economic activities, including formal and non-formal education, across the world at lightning speed. By mid-April 2020, it had interrupted the formal education of nearly 1.6 billion students in 192 countries. COVID-19's disruption of education in Africa, and especially in southern Africa, has been severe for several reasons. However, educational responses to COVID-19 suggest that it has stimulated the appetite for developing educational innovations - silver linings to the COVID-19 cloud. This paper is based on interviews conducted with 56 parents, students and educators involved in formal and non-formal education in Botswana, Malawi, Namibia, South Africa, Zambia and Zimbabwe. We identified the main educational challenges in these countries as being concerned with adapting to: (i) online education and learning, (ii) continuity of education from home, and (iii) community-based learning in small groups. The silver linings that we identified are: (i) putting greater emphasis on finding contextspecific solutions to education and health problems (improvisation), which is important for educational relevance and reveals the value of local actors, (ii) making linkages between social and ecological systems clearer, which is making the value of education for sustainable development (ESD) in this century more explicit, and (iii) revealing structural inequality and justice issues in education, which draws attention to the need for urgently addressing them as part of transformative change in education and sustainable development.
\end{abstract}

Keywords: COVID-19, southern Africa, educational responses, transformative change, education for sustainable development

\section{Introduction}

The emergence and rapid spread of the novel coronavirus disease 2019 (COVID-19) has disrupted education systems in southern Africa and beyond. By mid-April it had interrupted the school, college and university-based learning of nearly 1.58 billion students, comprising about $91.4 \%$ of the world's enrolled learners in 192 countries (UNESCO, 2000a). In Africa, 262.5 million pre-primary and secondary school children, about $21.5 \%$ of the continent's population, are out of school because of COVID-19-related school closures (Save the Children, 2020). Consequently, the pandemic has affected students' rights to quality, safe 
and inclusive education and social engagement with peers and educators (INEE, 2020; UNZimbabwe, 2020).

In Africa, COVID-19's most consequential impacts on education have been identified as the widening of inequalities, increase in marginalisation, and the inability of the most disadvantaged students to pursue their studies and acquire knowledge and skills that support a healthy transition to adulthood (UN, 2020; UNDP, 2020; UNESCO IESALC, 2020). The most affected students include those whose foundational learning was not strong: girls, children and youth with disabilities, and refugee, migrant and displaced children (Education Cannot Wait, 2020; Save the Children, 2020). In southern Africa, where we conducted this research, digital learning challenges are more acute in rural communities with low levels of material resources, lack of internet infrastructure and information and communications technology (ICT) illiteracy.

Many educational responses, which include virtual and traditional forms of learning, are being developed. For example, the Southern African Development Community (SADC) and the United Nations Education, Scientific, and Cultural Organisation (UNESCO) have entered into an agreement to ensure that 'Learning-Never-Stops' in the 16 SADC member states. Under the agreement, SADC countries will be assisted to mobilise resources, implement context appropriate and equitable solutions on distance education and learning remotely (SADC \& UNESCO, 2020). SADC member states, including Botswana, Malawi, Namibia, South Africa and Zimbabwe, have developed Education Sector COVID-19 Response plans or strategies. In general, a phased educational response to COVID-19 has been adopted: (i) continue to provide education through distance learning during the pandemic, (ii) re-open the schools and resume face-to-face teaching when the pandemic is over, and (iii) restructure the organisation of teaching and learning to benefit from the lessons learnt in the first phase, especially concerning quality of services and equity (UNESCO IESALC, 2020). In line with this phased approach, the Zimbabwe Education Cluster COVID-19 Preparedness and Response Strategy (2020) has the following objectives, to:

- Ensure continuity of learning through the implementation of key activities aimed at quality of learning and well-being of teachers, learners and school communities during the COVID-19 emergency;

- Support teachers, learners and school communities to prevent the transmission and spread of COVID-19;

- Facilitate the safe return to quality learning for teachers, learners and school communities after the COVID-19 emergency (Zimbabwe Education Cluster, 2020, p. 3).

The response plan, which is similar to those across the SADC region, appears to be anchored in strengthening linkages between the school and its community, formal and non-formal education, as well as tackling COVID-19 as a health issue with serious educational repercussions. Against this background, this paper seeks to: (i) surface the educational challenges being faced in southern Africa; (ii) highlight some of the context-appropriate 
innovations; and (iii) reveal the silver linings for education researchers, educators and education evaluators. Our third objective was inspired by Allen, Rowan and Singh (2020) who said: "We are in this together, this just might generate one of the silver linings that emerges from the current crisis - a reconnection with those around us and a stronger sense of shared empathy and kindness for one another, as well as a greater appreciation for our beautiful planet" (p. 233).

\section{Methods}

In order to address the objectives of this paper, we conducted interviews, made observations of relevant developments in and around our respective communities, and analysed relevant documents. We interviewed a total of 56 people comprising primary and secondary school students, parents with children in schools or colleges, and teachers. The detailed composition of the interviewees can be found in Table 1 below. The interviews were conducted online, by phone or using WhatsApp voice notes (if the signal was a problem) with interviewees based in Botswana, Malawi, Namibia, South Africa, Zambia and Zimbabwe.

Table 1: Interviewees who participated in the study

\begin{tabular}{|c|c|c|c|c|c|c|c|c|}
\hline & 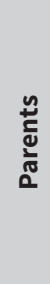 & 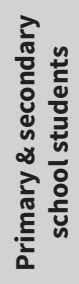 & 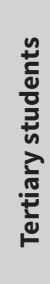 & 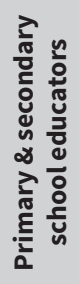 & 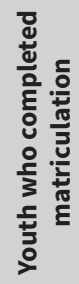 & 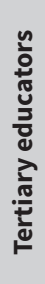 & 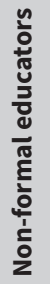 & $\begin{array}{l}\frac{u}{\pi} \\
\stackrel{0}{0}\end{array}$ \\
\hline Botswana & 1 & 1 & 1 & 1 & 0 & 1 & 0 & 5 \\
\hline Malawi & 0 & 6 & 6 & 2 & 0 & 1 & 0 & 15 \\
\hline Namibia & 1 & 0 & 2 & 2 & 0 & 1 & 0 & 6 \\
\hline $\begin{array}{l}\text { South } \\
\text { Africa }\end{array}$ & 4 & 3 & 0 & 2 & 2 & 0 & 4 & 15 \\
\hline Zambia & 0 & 0 & 0 & 0 & 0 & 0 & 1 & 1 \\
\hline Zimbabwe & 5 & 1 & 3 & 1 & 0 & 2 & 2 & 14 \\
\hline Totals & 11 & 11 & 12 & 8 & 2 & 5 & 7 & 56 \\
\hline
\end{tabular}

All interviewees responded to the following four core questions:

1. What educational challenges are you facing as a result of COVID-19 and its impacts?

2. What explanations or structural issues underpin the challenges you are facing? 
3. What local, traditional and/or indigenous responses to similar crises can be utilised developing effective educational responses to COVID-19?

4. What creative and innovative ways have you found useful to address COVID-19 challenges in learning and education?

Responses led to the development of several themes which are discussed in the results below. Firstly, several COVID-19 related challenges emerged which required adaptation by all involved, including online learning, education at home. In response to these challenges, context-appropriate improvisations are emerging, resulting in what can be regarded as several silver linings for educators.

\section{COVID-19 related educational challenges being faced in southern Africa}

Several COVID-19 related challenges emerged from the interviews that require significant adaptation by all teachers, learners and their parents. These include adapting to online learning and learning via radio and television programmes, the continuity of education from home, facilitated community-based learning, as well as the new costs of learning.

\section{Adapting to online education and learning}

Educators, educational researchers, community-based popular educators and education evaluators in southern Africa are facing challenges associated with using online facilities as a primary means for carrying out their duties. For example, a respondent in the non-formal education sector of Zambia who has been facilitating a 'Building resilience in the road sector train-the-trainer' course faced challenges using online facilities. This is partly because the educator and participants have varying degrees of online-based facilitation and learning experience. Another educator in Zimbabwe faced a similar challenge in conducting online training in permaculture (a practice-based sustainable agriculture approach). A laboratory technologist and lecturer in fisheries (freshwater and marine) and aquatic sciences at a university in Namibia was challenged to conduct practical demonstrations and fieldwork to develop students' practical competences. Group-based learning has also been disrupted as a result of the shift to online learning and the need for observing social/physical distance to manage the spread of COVID-19. As lockdown eased in some countries, the convenors of informal educational activities faced unexpected costs to ensure the safety of participants and facilitators. For a small permaculture NGO in South Africa, these unexpected costs included purchasing masks and hand sanitisers as well as running more workshops than originally planned (due to the planned number of participants per workshop being higher than what was permitted under COVID-19 regulations). An NGO in Zimbabwe, which works with schools and teacher colleges in permaculture, incurred additional costs having to train its facilitators (teachers) on COVID-19.

Many educators, learners and parents in southern Africa have inadequate or no access to computers, laptops and cell phones, which are necessary for online teaching and learning. 
Some lack money to buy data bundles, while others do not have radio or television. Families with too few computers have to compete for the limited resource, with parents needing to use the computers for work and adult learning, and children needing to use them for school and college work. To add to this, frequent power outages in the region further limit the time that is available for working on shared computers. For example, a university student in Malawi explained, "I do not have a laptop. When I am given an assignment, I go and borrow a laptop. I depend on my parents for data bundles." Parents in Zimbabwe described how their children were struggling because of limited connectivity as outlined by this parent of primary school children:

Kids' school opened a virtual class but are having the challenge to use interactive classes like Google class, and end up using WhatsApp, sending voice notes and also assignments. The kids ... need constant supervision and help. In my situation, it was difficult as both of us [parents] [go] to work. Then the lessons and even assignments have not [been] consistent, and also the quality of delivery was poor. The classes for zero grades were also discontinued - probably because of lack of content.

In another example from rural South Africa, a sibling attempting to help younger brothers and sisters had to rely on what had been learnt at school due to no internet connectivity to access teachers' emails or online resources.

All educators interviewed in this study stressed how their workload had increased due to virtual learning. They were also finding it difficult to get across new and difficult concepts to children via non-interactive virtual lessons. The shift to online learning is reshaping an accustomed pedagogy as well as the quality of learning across the region. For example, a primary school teacher in South Africa was finding it difficult to ensure coherent lessons due to limited interaction, and could not find adequate teaching methods to cater for different learning abilities and she struggled with evaluating the learning. A primary school student in South Africa said she avoided online lessons for subjects she did not like, was disturbed by pupils who posted jokes during online lessons, felt cyberbullied by pupils who wanted to attend all lessons and was irritated by teachers who called her when she did not attend virtual lessons.

The number of students who have access to online learning but are not willing to use it is another challenge. This is illustrated by the experience of a 15-year old girl at a wellresourced secondary school in South Africa, who got up late and quickly lost interest in her work due to lack of support. She attended Zoom classes but felt they were not working for her. By the end of a particular Zoom-based Chemistry lesson, all but two learners had left the class. Although the teacher could see the dwindling numbers, she kept on teaching the class and conducted another Zoom-based lesson session the following week with two learners only. The 15-year old girl concluded that her teacher did not care how students felt or coped. Her teacher was equally frustrated for different reasons: the school was not investing enough resources to address the new educational challenges, and teachers could not adjust the implemented curriculum to address COVID-19 educational challenges. 
Another South African teacher also felt that too much attention was being paid to the 'correct curriculum' in a time of crisis. He felt that the attempt to stick to a pre-COVID-19 curriculum indicates how the education system is not seriously adapting to the current existential crises. He said, "We should be engaging our students in what is happening to them right now and helping them to make sense of this, increasing their ability to adapt rather than reading Shakespeare because it is in the curriculum." An issue of vocabulary was raised when WhatsApp platforms are used for online teaching. Students are using shorthand such as "L8r" for "later", and "plz" for "please", as common conventions in informal WhatsApp conversations. The teacher felt that using this convention in formal communication was undermining the curriculum standards in language subjects.

\section{Adapting to the continuity of education from home}

The closing of schools and banning of public gatherings has shifted student and adult education and learning from the schools and other non-formal education sites to their homes. This has made the home a place for continued education and learning. But not all homes in southern Africa are suitable for student and adult learning. At a very basic level, many families do not have the space for both parents and students to work from home, which leads to competition for the use of limited home space for teaching, learning and work. For example, university lecturers from five South African universities collaborating on a climate change education research project, reported competing with spouses and children who also need space and privacy to do their work.

For students, homeschooling also surfaces educational quality and equity issues, which arise from differential access to digital devices to work and learn online. A parent in Zimbabwe shared how her four children in different classes have to compete for one digital device to support their online learning. Many parents were either unwilling or unable to provide the necessary enabling learning environment and support in the home. Learning from home is done online and through radio and television programmes, which is creating new learning and work challenges. These teaching modalities are not suitable for all students. For example, in Malawi learners with disabilities such as hearing and visual impairments have to depend entirely on family members to help them with home-based learning. Yet, some of these learners live with family members who do not have basic knowledge of sign language for using with those with hearing impairments, for example (Muchanga et al., 2020).

A parent in Zimbabwe emphasised that she, like most parents, was not an educator and was not in a good position to support and supervise her students to learn from home. This was echoed by a parent in South Africa who said education institutes have unrealistic expectations about home support. Parents' educational support to their children has been identified as a key challenge for single parents, especially if they are from the working class. Parents whose homes are in remote areas face different challenges with child education. For example, in Botswana, some parents sent their children to herd cattle in remote grazing 
lands where children would be safe from the pandemic. Consequently, the children were cut off from the possibility of home schooling.

Women and girls are facing greater workloads when learning and working than their male counterparts. A woman in South Africa explained how COVID-19 and working from home had increased her burden of work. Her working day started at 5:30 am and ended around 5:30 pm, as she had to perform her usual duties as well as conduct several meetings online. In the evening she helped her child with homework. She found it stressful when she was not able to help her daughter as much as she would have liked and then received a call from the school concerning work that had not been submitted (with no concern for the struggles she and her child had trying to do the work). A Zimbabwean lecturer at a South African university says COVID-19 has redefined the meaning of being a breadwinner: it no longer simply means being able to fend for one's family through providing money to spend but includes being able to work in localised and creative ways. This is creating new challenges for breadwinners working in the diaspora, especially men.

\section{Adapting to facilitated community-based learning}

COVID-19 has also pushed face-to-face teaching at educational institutions to migrate to distance and virtual learning. This presents a new challenge to high-quality education as a social experience requiring routine human interaction (Béteille et al., 2020). The chlenge has been particularly intense because educators have had no time to prepare "to adapt to the modalities of virtual and distance teaching, managing virtual spaces and classes, engaging students in new and innovative ways of learning" (ILO, 2020, p. 2). Transforming face-to-face classes to a virtual mode has created a steep learning curve for many educators, undermining the quality of learning in some cases (UNESCO IESALC, 2020). The situation is worsened by the fact that, for the learners, pedagogical continuity under these circumstances favours the digitally literate, with physical and financial access to virtual learning. In Africa, the proportion of households with internet connectivity is very low, at $20 \%$ (UNESCO IESALC, 2020). The proportion of learners with internet access in subSaharan Africa is even lower, at $18 \%$, while those with access to household computers is a mere $11 \%$ (UNESCO, 2020b). At the same time, parents, whose technical, technological and academic capacities vary considerably, are also having to play greater roles to support their children to learn through distance and virtual education (ADEA, 2020). These digital divides have prompted student bodies such as the South African Students Congress (SASCO), the University of Malawi Students Union (UMSU) and the Zimbabwe National Students Union (ZINASU) to reject e-learning as the educational solution in Africa (Mukeredzi, Kokutse \& Dell, 2020).

The travel restrictions have made it difficult for some planned educational activities to be implemented. The restrictions in the number of people who can gather at a place as well as the health standards that must be adhered to, such as washing hands using sanitisers, and wearing masks, is created other challenges. For example, a CBO operating in Limpopo 
Province to facilitate the learning and implementation of permaculture to increase food security and protect the environment, is having to train fewer people at a time. This is because they have to observe social distance requirements, provide masks and sanitisers. This has created the need for raising extra funding for masks. When the training was implemented, and the participants wore masks, they also found it psychologically hard to adjust to not seeing each other's faces. In Zimbabwe, COVID-19 has disrupted communitybased research and learning on the impact of Cyclone Idai in Chimanimani District of Zimbabwe. Travel restrictions made it impossible for researchers from outside Chimanimani District to visit and complete some aspects of their planned research work with the district communities. The participatory action learning oriented research is intended to increase community adaptive capacities and improve community livelihoods. Such delays in the implementation of facilitated community learning have been undermining much-needed development in the southern African region. In some cases, facilitated community learning has been encountering online learning challenges as highlighted earlier and illustrated by Zimbabwean and Zambia experiences. The challenges include lack of capacity to do online learning, and lack of necessary equipment and infrastructure to support online learning. This has meant that community members who cannot access online learning are being left behind.

We also established that many community members who would like to participate in facilitated community learning processes are constrained by lack of time and lack of resources. Some are having to spend more time raising income to meet family needs because the sources of their income are being negatively impacted on by COVID-19. For example, community members involved in farming and dependent on income from agricultural produce, have been facing marketing challenges due to travel restrictions. Many employees, especially in the tourism and travel sectors, have been losing their jobs due to lack of demand for their services. Consequently, they are having to prioritise income-generation over participation in community learning.

\section{Context-appropriate improvisations in response to COVID-19}

Our interest in finding silver linings to the COVID-19 crisis made us ask questions about innovative educational responses. But it was too early to start talking about 'innovations' because there has not been enough time to prove their effectiveness. Rather, we find it more appropriate to talk about 'improvisations', which refer to exploration, experimentation and knowledge creation to maintain effectiveness to cope with turbulent and uncertain times (Hitt, 2000; Leybourne \& Kennedy, 2015). Green (2009) said improvisation occurs when agents invent in the interplay between freedom and constraints. Similarly, Sridharan (2020) described improvisation as the ability to adapt or to deal with surprises so that we have the best chance of survival. When successful improvisation goes beyond survival it can lead to innovation that enhances effectiveness and value creation by the improviser and by other actors, while enabling continuous improvement of practice (Leybourne \& Kennedy, 2015). 
Improvisation also includes the ability to "ingenuously adapt to a set of circumstances" (Preston, 1991, p. 88) and devise "resourceful solutions to intractable problems" (Meyer, 1998, p. 572).

\section{Transforming to blended learning beyond COVID-19}

A South African university in the Eastern Cape Province has been escalating its efforts at blended learning and enhancing its effectiveness. A learning and research centre at the university has traditionally held a weekly face-to-face reading circle to enhance peer support and learning for PhD scholars. But COVID-19 has rendered the face-to-face learning moments almost impossible due to expenses associated with short-term transport and travelling to and from the university. Vehicles that are authorised to transport passengers in line with COVID-19 restrictions have had their carrying capacities halved resulting in a doubling of the transport fee to maintain the viability of the transport business. Prior to COVID-19, the university had established an online platform for off-campus students which proved useful for all students during COVID-19. One lecturer reported giving more appropriate support to her postgraduate students, by taking into account the contexts in which they are learning. The university itself has responded by providing other support for students such as laptops and data bundles, which was already needed by some students before COVID-19.

\section{Expanding mandates to respond to the most urgent issues}

Sridharan (2020) referred to an organisation's ability to adapt as 'fungibility', an example being whether organisations could move from being developmental (or educational) organisations dealing with developmental issues, to dealing with a crisis. We identified a particularly interesting example of how a community-based organisation (CBO) is being fungible in South Africa. The CBO only works in one community where its mandate is to alleviate poverty by running a year-long permaculture course where women are taught how to grow food and basic business skills and given psychological support. None of the women they work with have enough income to even reach the UN poverty datum line (US $\$ 1.90$ per day). COVID-19 curtailed their livelihood options even further. Most of the women supplemented their social grants by selling vegetables from their gardens, but street vendor selling was not allowed under lockdown restrictions. Small amounts of money they may have received from relatives or estranged partners immediately stopped as many people found themselves unable to work for an income under lockdown. In this situation, the small CBO was 'fungible' enough to respond almost immediately. They partnered with a local orphanage and began raising funds for food parcels. The vegetables grown by the women were bought and included in the food parcels. A new obstacle emerged: Government required NGOs apply for a permit to distribute food parcels to ensure the food was safe for consumption. However, local municipality offices that needed to issue the licenses were closed. Under these circumstances, the CBO team decided to go ahead with distribution 
anyway. They did their best to avoid military roadblocks but found local police roadblocks waved them through as the people they were feeding were known to the local police who understood how much in need they were. In this case, the CBO team found itself in a difficult position where they had to make sense of the rules and procedures, interpret them and use their sense of judgment (Lipsky, 1980) in dealing with ambiguous and non-routine situations (Maynard-Moody \& Musheno, 2003).

\section{Improvisations to support livelihoods}

One of the greatest challenges for southern Africa during COVID-19 has been food security. Our findings showed that organisations have had to shift from providing training to ensuring people get enough to eat. We have discovered that there is a lot to learn from people about innovations in a crisis. The COVID-19 crisis connects us back to the source of what keeps us alive - the earth, water and what grows. We have observed several improvisations in and around our homes. We have also seen an escalation of efforts to improve food selfsufficiency and reduce the need to buy groceries frequently while at the same time making home a pleasant environment with recreation. For example, one family in urban Harare has begun keeping free-range chickens, ducks and rabbits in their orchard and is using their garage to keep broilers. We also observed some individuals sending money not only to their families but also to colleagues and friends to help sustain their home food gardens. We have noticed that gardening is not only helping with food and income but also enabling greater focus on the use of locally available resources and learning of survival skills. Virtual libraries have become an important ally in this process of improvisation. For example, a woman who was trying to cut the costs of feeding ducks and chickens has learnt how to produce duckweed, which is far cheaper to produce and yet more nutritious than most store-bought feed.

\section{Addressing physical and emotional distance of learning during COVID-19}

When the immediate risk of starvation had been addressed, the CBO team mentioned earlier began to consider other issues created by the crisis. It seemed urgent to start a new permaculture course and the team began thinking through how they would run the course within the context of COVID 19. In the previous course, the fences and shade cloth structures had only been constructed around the women's gardens six months into the year. This needed to change as the NGO team realised the women needed to start growing immediately. Once the workshops started, the participants and team found it difficult not seeing each other's full faces and the distance between them was felt on both physical and emotional levels. The permaculture trainer remarked, "COVID-19 has taken away our smiles". The NGO team took photographs of all the women with their masks both on and off. These pictures were shared with the women so that they could consider how we read faces when we can see whole faces. The CBO made brooches with the unmasked face of each woman which could be worn during class so everyone's whole face could be seen. 


\section{Introspection and activism to tackle educational quality and equity challenges}

COVID-19 has made researchers in the Global North more aware of their reproduction of colonial practices that silence local research partners through a monopoly on proposal design, selection of design theories, and methodologies for monitoring. In Africa, we have observed that COVID-19 has stimulated stronger activism from learners, educators and human rights movements, especially around structural issues related to access to education, health and livelihoods. Student movements have joined hands to reject digital learning as an educational solution in Africa when digital access is limited to the elite. Teachers in southern Africa have also been resisting the opening of schools before adequate health and learning requirements are met. In Zimbabwe, the nine (often-competing) teacher unions combined efforts to successfully prevent schools from opening under circumstances where both educators and learners would be exposed to the virus. A parent in South Africa spoke about his resistance to his children returning to school, commenting that he did not see why children needed to be the experiments of COVID-19. Through his activist and political networks, he also reported on how the opening of schools was linked to crony tenders for hand sanitisers and protective equipment for schools in his area.

A South African activist described how the COVID-19 crisis has exposed elements of systemic violence towards ordinary people by the state. He shared how pensioners were queuing for their pensions when the military arrived and without any warning or explanation began beating people who were not socially distancing. He shared how a person does not receive a food parcel unless that person is a political party cardholder. When asked about resistance, he explained that people were scared: "We remember too well what happens when the military arrives". He linked this to his own experiences as an activist under apartheid having to flee from the military. "There is nowhere to run to and hide now as we can't leave our homes. This makes activism and resistance very hard but we are now seeing the full extent of the damage to our democracy through COVID-19 and we won't forget."

\section{Silver linings for educators, education researchers and evaluators}

Despite all the pedagogical and contextual hurdles being encountered, there seem to be silver linings for educators, education researchers, popular educators and evaluators. These are still forming and the direction they will take is not yet certain. They include: (i) more contextualised responses to education and learning, (ii) strengthening the link between education and sustainable development, and (iii) fostering of responsible educational activism. 


\section{More contextualised educational responses}

Our study has revealed moments where people have been able to improvise quickly to the context of the communities they serve. The Ministries of Education in various SADC countries have developed responses that are suitable for those with access to digital resources as well as those without. This is illustrated by Botswana, Malawi, Namibia, South Africa and Zimbabwe having developed Education Sector COVID-19 Response plans or strategies. Schools and universities have developed learning materials and provided instruction via different online facilities, intended to provide for the majority of students. This has been illustrated in formal education in South African and Zimbabwe and the informal education sectors of Zambia and Zimbabwe. Parents have converted their homes for home schooling, workplace learning and for doing some of their professional work. Organisations involved in non-formal education have rescheduled their work, included COVID-19 training in their curriculum, and devised new strategies to enable education and learning to continue taking place. In the process, the different actors in the education system have exercised their creativity and tapped into their agency to find and implement context-specific solutions to education and health problems (often through improvisation).

\section{Strengthened link between education and sustainable development}

The emergence of the pandemic has been linked to the way humans have exploited the planet on which life depends. The pandemic has also compelled international and national organisations across different sectors to develop response strategies at an unprecedented scale and pace. For example, the World Health Organisation, the United Nations Food and Agriculture Organisation (FAO), UNESCO, UNDP, international climate organisations, SADC and its Member States have all been developing responses to the pandemic. At the same time, urban households have been adapting by producing more vegetables and keeping small livestock in smallholdings. In the process, they have increased household food production and acquired new life skills. This could lead to an accelerated promotion of Education for Sustainable Development (ESD) and usefully highlights the intersectionality between ESD and livelihoods.

\section{Fostering of responsible education activism}

Our study has shown that structural inequalities are also negatively impacting on the adequacy and effectiveness of COVID-19 responses in education by favouring those with digital access. This has resulted in student bodies in the SADC region rejecting digital education as the solution to the disruptions caused by COVID-19 in education. The student bodies comprise students from well-to-do families as well as poorly resourced families. This kind of solidarity between students who have and those who do not, can be seen as responsible education activism. Educators on their part have put their heads together and fought against continued schooling that exposes learners and educators to the virus. We view this as responsible education activism as it ensures that the learners and educators' health and livelihoods are considered alongside continued education. This kind of activism 
is needed in the future to ensure that curricula and assessments are appropriate in current times and different contexts.

\section{Conclusion}

COVID-19 has most certainly highlighted the shortcomings of the current education systems in terms of inequality and the ability to be responsively relevant. The inequalities in education are closely tied to historical and current everyday structural inequalities. This challenges educators to rethink what to teach and how to teach. The silver linings of the COVID crises point to educational improvisations that may need to be explored and expanded further for future use.

\section{Notes on Contributors and their Contributions}

\section{Lead author}

Mukute, Mutizwa

Mutizwa Mukute holds a PhD in Environmental Education. He is a senior research associate with Rhodes University and his environmental learning and evaluative research focuses on sustainable agriculture and food systems, biodiversity and natural resources management, climate change education and climate change adaptation.

\section{Co-author}

Burt, Jane

Jane Burt has recently completed a $\mathrm{PhD}$ in cognitive justice and environmental learning in social movements through Rhodes University. She is the director of 'realife learning' where she practises transformative learning and monitoring and evaluation.

\section{Co-author}

Francis, Buhle

Buhle Francis is an agent of change environmental scientist who is part of the One Ocean Hub Project. She is undertaking a $\mathrm{PhD}$ in environmental science and holds an MPhil in Environmental Management. Her research interests range from monitoring and evaluation of environmental pedagogy to the green economy.

\section{Co-author}

De Souza, Ben

Ben de Souza is currently a Canon Collins Scholar in the Department of Education at Rhodes University. Ben holds a Bachelor of Education degree from the University of Malawi. His Master of Education research at Rhodes combines public policy, disability law and inclusive education. 


\section{Percentage contribution}

\begin{tabular}{|c|c|c|}
\hline Areas of contribution & Author & $\begin{array}{l}\text { Percentage } \\
\text { contribution }\end{array}$ \\
\hline \multirow{4}{*}{ Conception or design of the paper, theory or key argument } & Mukute & $60 \%$ \\
\hline & Burt & $20 \%$ \\
\hline & Francis & $10 \%$ \\
\hline & De Souza & $10 \%$ \\
\hline \multirow{4}{*}{ Data collection } & Mukute & $25 \%$ \\
\hline & Burt & $25 \%$ \\
\hline & Francis & $25 \%$ \\
\hline & De Souza & $25 \%$ \\
\hline \multirow{4}{*}{ Analysis and interpretation } & Mukute & $50 \%$ \\
\hline & Burt & $25 \%$ \\
\hline & Francis & $15 \%$ \\
\hline & De Souza & $10 \%$ \\
\hline \multirow{4}{*}{ Drafting the paper } & Mukute & $50 \%$ \\
\hline & Burt & $25 \%$ \\
\hline & Francis & $15 \%$ \\
\hline & De Souza & $10 \%$ \\
\hline \multirow{4}{*}{ Critical review of the paper } & Mukute & $20 \%$ \\
\hline & Burt & $20 \%$ \\
\hline & Francis & $35 \%$ \\
\hline & De Souza & $25 \%$ \\
\hline
\end{tabular}

\section{References}

Allen, J. Rowan, L. \& Singh, L. (2020). Teaching and teacher education in the time of COVID-19. Asia-Pacific Journal of Teacher Education, 48(3), 233-236.

ADEA (Association for the Development of Education in Africa). (2020). Delivering education at home in African member states amid the COVID-19 pandemic: Country status report. Abidjan, Ivory Coast: ADEA.

Béteille, T., Ding, E., Molina, E. Pushparatnam, A. \& Wilichowski, T. (2020). Three principles to support teacher effectiveness during COVID-19. Washington DC: World Bank.

Education Cannot Wait. (2020). COVID-19 and education in emergencies. Retrieved from: https://www.educationcannotwait.org/covid-19/ 
Hitt, M.A. (2000). The new frontier: Transformation of management for the new millennium. Organizational Dynamics, 28(3), 7-17.

ILO (International Labour Organization). (2020). COVID-19 and the education sector. ILO Sectoral Brief. Geneva, Switzerland: ILO.

INEE (Inter-Agency Network for Education in Emergencies). (2020). Technical Note: Education during the COVID-19 pandemic. INEE, New York, USA. Retrieved from: https://inee.org/resources/inee-technical-note-education-during-covid-19-pandemic

Leybourne, S.A. \& Kennedy, M. (2015). Learning to improvise, or improvising to learn: knowledge generation and 'innovative practice' in project environments. Knowledge and Process Management, 22(1), 1-10.

Lipsky, M. (1980). Street Level Bureaucracy: Dilemmas of the individual in public services. New York: Russell Sage Foundation.

Maynard-Moody, S.W., Musheno, M. \& Musheno, M.C. (2003). Cops, Teachers, Counselors: Stories from the front lines of public service. Michigan: University of Michigan Press.

Meyer, A. (1998). Organizing for improvisation: The backstage story of the Vancouver jazz concert and symposium. Organization Science,18, 511-522.

Muchanga, M., De Souza, B., Negumbo, E., Tembo, T., Chipere, R.T., Nhnyete, S., Garapo, N.L., Coetzee, M., \& Madiba, M. (2020). Exploring Educational Lives of the Excluded Youth under COVID-19 in the SADC region. Johannesburg: JET Education Services. Retrieved from: https://www.jet.org.za/covid19research-response/sadcresearchchallenge/themes/theme-3

Mukeredzi, T., Kokutse, F., \& Dell, S. (2020). Student bodies say e-learning is unaffordable and elitist. Retrieved from: https://www.universityworldnews.com/post. php?story $=20200422075107312$

Preston, A. 1991. Improvising order. In I.L. Mangham (Ed.), Organization Analysis and Development, Vol. 22. New York: John Wiley \& Sons, pp. 308-325.

SADC \& UNESCO. (2020). SADC \&UNESCO sign agreement to ensure learning never stops. Press Release. SADC \& UNESCO: Gaborone, Botswana/Harare, Zimbabwe.

Save the Children. (2020). Save the Children: Outbreak could cause millions of children to suffer for years to come. Retrieved April 16, 2020 from: https://www.savethechildren. org/us/about-us/media-and-news/2020-press-releases/outbreak-could-cause-years-ofsuffering-for-millions-of-children

Save the Children East and Southern Africa Regional Office \& Save the Children West and Central Regional Office. (June 2020). COVID-19 impacts on African Children: How to protect a generation at risk. A Pan-African Policy Paper. Nairobi, Kenya/Dakar, Senegal: Save the Children International.

Sridharan, S. (2020). Incorporating Equity and Complexity into our Theories of Change. Webinar. Toronto: The Evaluation Centre for Complex Health Interventions.

UN (United Nations). (2020). Policy brief: Education during Covid-19 and beyond. Retrieved from https://www.un.org/sites/un2.un.org/files/sg_policy_brief_covid-19_ and_education 
UNDP (United Nations Development Programme). (2020). Human development perspectives Covid-19 and human development: Assessing the crisis, envisioning the recovery. Retrieved from http://hdr.undp.org/sites/default/files/covid-19_and_ human_development_0.pdf

UNESCO (United Nations Educational, Scientific and Cultural Organisation). (2020a). COVID-19 educational disruption and response. Retrieved from: https://en.unesco. org/news/covid-19-educational-disruption-and-response 13 Apr. 2020

UNESCO (United Nations Educational, Scientific and Cultural Organisation). (2020b). Startling digital divides in distance learning emerge. Retrieved from: https://en.unesco. org/news/startling-digital-divides-distance-learningemerge\#ShareEducation

UNESCO-IESALC (United Nations Educational, Scientific and Cultural Organisation International Institute for Higher Education in Latin America and the Caribbean). (2020). COVID-19 and higher education: Today and tomorrow. Impact analysis, policy responses and recommendations. Retrieved April 9, 2020 from: http://www.iesalc. unesco.org/en/wp-content/uploads/2020/04/COVID-19-EN-090420-2.pdf

UN-Zimbabwe. (2020). Immediate socio-economic response to COVID-19 in Zimbabwe: A framework for integrated policy analysis and support. UN-Zimbabwe: Harare, Zimbabwe.

Zimbabwe Education Cluster. 2020. Humanitarian response and COVID-19 situation report. Retrieved May 14, 2020 from: https://www.humanitarianresponse.info/en/ operations/zimbabwe/education 